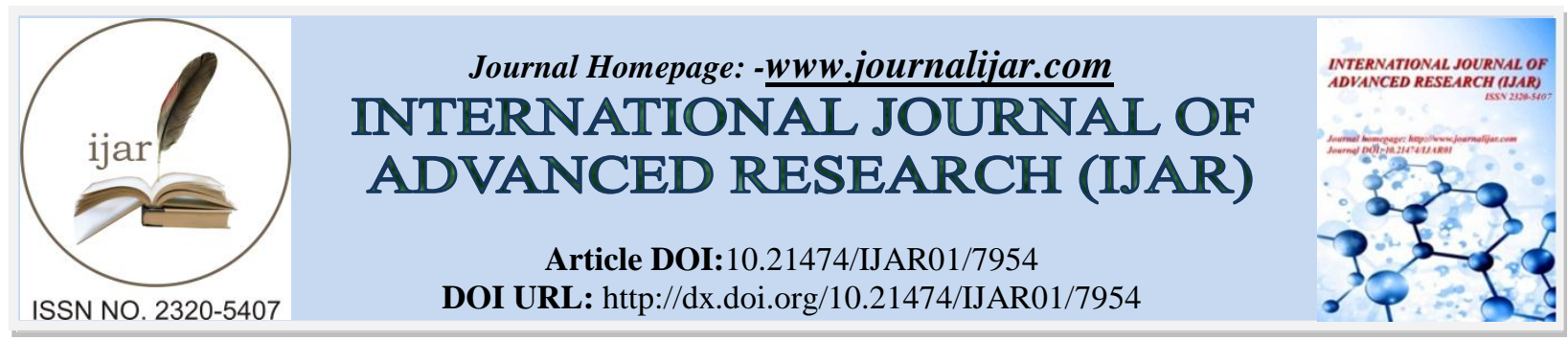

RESEARCH ARTICLE

\title{
STUDY OF STREET VENDORS ARRANGEMENT IN THE BIG CITY AS THE TOURISM POTENTIAL OF THE CITY CASE STUDY: THE STREET VENDOR ARRANGEMENT IN BANDUNG AND SOLO , INDONESIA.
}

\author{
Siti Azizah. \\ Department Of Architecture, Institut Teknologi Adhi Tama Surabaya.
}

\section{Manuscript Info}

Manuscript History

Received: 17 August 2018

Final Accepted: 19 September 2018

Published: October 2018

Keywords:-

street vendors, policies, city tourism.

\begin{abstract}
The problem of street vendors is a complicated problem of cities in developing countries. For this reason, the local government needs to make policies to overcome the problem of street vendor. The purpose of this study is to study some of the policies applied to street vendors in several cities that have changed the imageof street vendors are unattractive and disturbing to become one of the city's tourism potentials. The case study took 2 major cities in Indonesia that have made policies by placing street vendors in a place and making them attractive tourists to visit the city. In the Bandung City, street vendors are relocated to a bridge building on Cihampelas road which is attractively arranged with a beautiful trading place design and other supporting elements. Whereas in the Solo City, PKL is placed in a place that features a variety of famous culinary from the Solo city. Both city government policies are able to make street vendors survive and continue their lives and they become one of the potential cities that attract tourists.
\end{abstract}

Copy Right, IJAR, 2018,. All rights reserved.

\section{Introduction:-}

The problem of street vendors is a complicated problem of cities in developing countries. For this reason, the local government needs to make policies to overcome the problem of street vendor. The purpose of this study is to study some of the policies applied to street vendors in several cities that have changed the image of street vendors are unattractive and disturbing to become one of the city's tourism potentials. The case study took 2 major cities in Indonesia that have made policies by placing street vendors in a place and making them attractive tourists to visit the city. In the Bandung City, street vendors are relocated to a bridge building on Cihampelas road which is attractively arranged with a beautiful trading place design and other supporting elements. Whereas in the Solo City, PKL is placed in a place that features a variety of famous culinary from the Solo city. Both city government policies are able to make street vendors survive and continue their lives and they become one of the potential cities that attract tourists.

According to Bromley, R (2000) The existence of street vendors in urban problems is responded in two opinions, some think they only create problems and must be removed from the city but some justify their continued life in the city. Further according to Madanipour, A (2004) the rejection of street vendors in the city is a manifestation and exclusion society in several cities. The exclusion the society causes irregularities in the public sphere. In line with 
this according to Andri Y (2008) of Although there are eliminate street vendors but they will not disappear, because no one can replace street vendors in the economic city. Meanwhile, according to Ala'Eddin (2012) there are many important factors in design from traditional markets to modern shopping centers. The factors are economic problems, prosperity, lifestyle changes, differences in culture, ethnicity and condition of the room. According to Azizah, Siti (2007), to create environmental aesthetics related to street vendors in the city center is attempted with a physical arrangement model in the form of street vendors zoning according to the type of merchandise.

The results of Azizah, Siti (2017) research are about the design of culinary centers in Surabaya that are favored by street vendors and users. The research results are locations that are close to other public facilities, so that it becomes an alternative destination or stopover, the building forms are modern in style, the interior has a relaxed but dynamic atmosphere, shaded and green exterior and supporting facilities such as entertainment stage. According to Sitanaya, Octofiany and Handinoto, (2012), Facilities in Culinary Tourism are public spaces that can highlight the function of culinary tourism. These facilities include food court, coffee shop, souvenir shop, recreation area and also supporting facilities such as play ground, multipurpose room, book cafe, meeting room, management and service office.

\section{Methodology:-}

The method is comparing several street vendor arrangement in several cities. The aspects reviewed are building design, environmental arrangement, supporting facilities, and potential tourism. The object of study is two areas of street vendor arrangement in big cities in Indonesia, they are Bandung and Solo city.

\section{Result:-}

\section{Case Study of Street Vendor Arrangement in Bandung City, Indonesia:-}

Bandung government Regulation Number 4 of 2011 concerning PKL Arrangement and Guidance is a good step from the previous Bandung city government to overcome the street vendor problem. With the publish of this Regional Regulation, of course the implementation must be carried out accompanied by strict supervision from both the government and the community working together to organize a better Bandung City in order to achieve a safe, clean and orderly City.

Bandung government Regulation Number 4 of 2011 concerning the Arrangement and Guidance of PKL. i.e. there is a red zone where street vendors are prohibited from selling in the zone, then there is a yellow zone where PKL is allowed to sell at certain hours, and finally there is a green zone in this zone PKL may sell without a time limit.

In connection with the above regulation, a series of activities and policies were carried out by the Bandung City Government, namely the implementation of a strategic arrangement concept, namely making the PKL area. To achieve this strategy, the ways that Bandung City Government does are as follows:

1. Relocation, this activity is carried out if there is no land in the location and the number of street vendors is too much;

2. Knock Down Shelter, street vendors will be built if the land is still available;

3. Tents, carried out in areas where land is available and PKL only conducts activities at night;

4. Carts, carts are provided in areas where the land is not available for shelter and tents. Carts are more mobile, can be moved at any time;

5. Control, as the last step if street vendors remain stubborn, do not want to follow the municipal administration program.

The regional regulation also regulates the placement of zonanisasi for PKL: PKL locations are divided into 3 (three) zones as follows:

1. Red zone is a location where there is no PKL; For red zones where there is no PKL, namely the area around the place of worship, hospitals, military complexes, national roads, provincial roads and other places that have been determined in the legislation unless otherwise determined by this Area Regulation

2. Yellow zone is a location that can close open based on time and place; inside the yellow zone there are 3 parts that allow PKL to sell.

3. Green zone is a location that is allowed to trade for street vendors. Green zones are certain areas based on the results of relocation, market revitalization, the concept of automatic shopping, the concept of the festival and the Pujasera concept in accordance with applicable regulations.

One of the locations for the relocation of street vendors in Bandung is the Sky Walk Cihampelas. 
Sky walk Cihampelas is a pedestrian-bridge. Cihampelas terrace has a length of about 500 meters and a width of about 7-8 meters. This building stands on Jalan Cihampelas. This bridge is designed differently so that it remains comfortable for pedestrians even though the street vendors sell along the bridge.

Local potential in attracting visitors is placed here. Strength in Bandung is in souvenir items, souvenirs, and fashion, such as shirts, jackets and bags. the potential is visible on this Cihampelas Terrace. The culinary is also presented with a kiosk that is neatly arranged and clean.This location is a pedestrians way. Besides being a pedestrian way, Teras Cihampelas is also a place for street vendors who usually sell at Jalan Cihampelas.

To add a beautiful impression, also built a green line, in the form of small plants that are on both sides of the bridge. In this location also appeared a number of facilities such as seats, photoboots, toilets, lighting lamps.
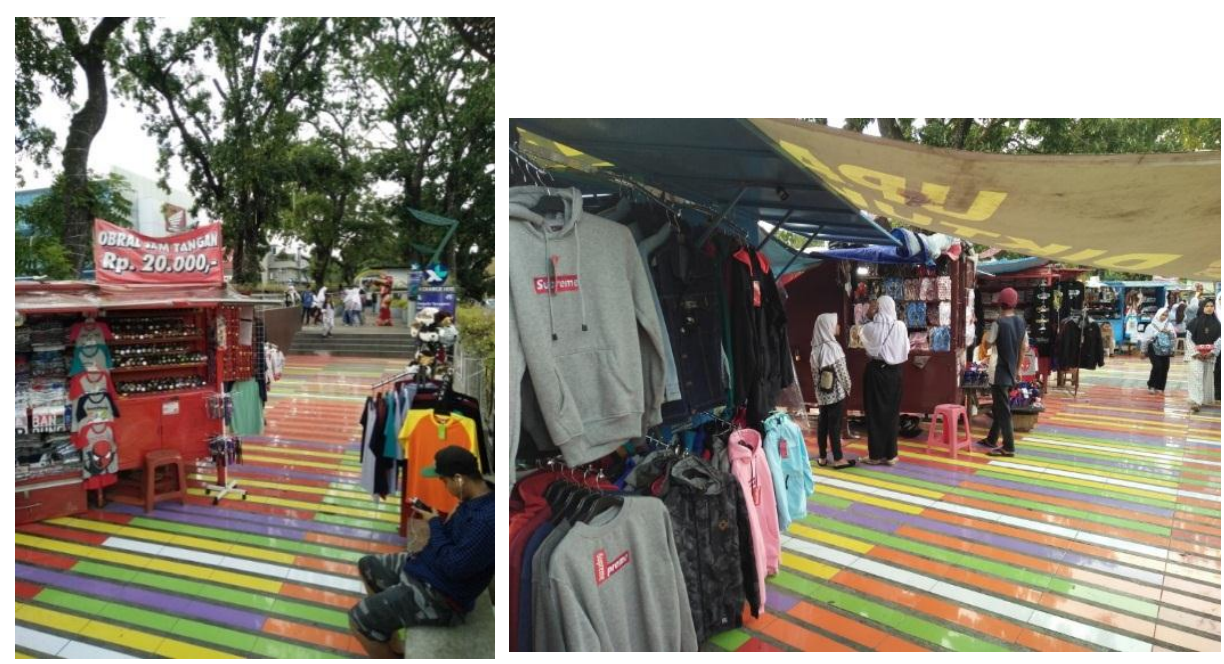

Fig. 1:-The trade of Bandung fashion goods is one of the attractions of this area. The attractive design of floor patterns in this area is not make boring as a tourist place or a walk
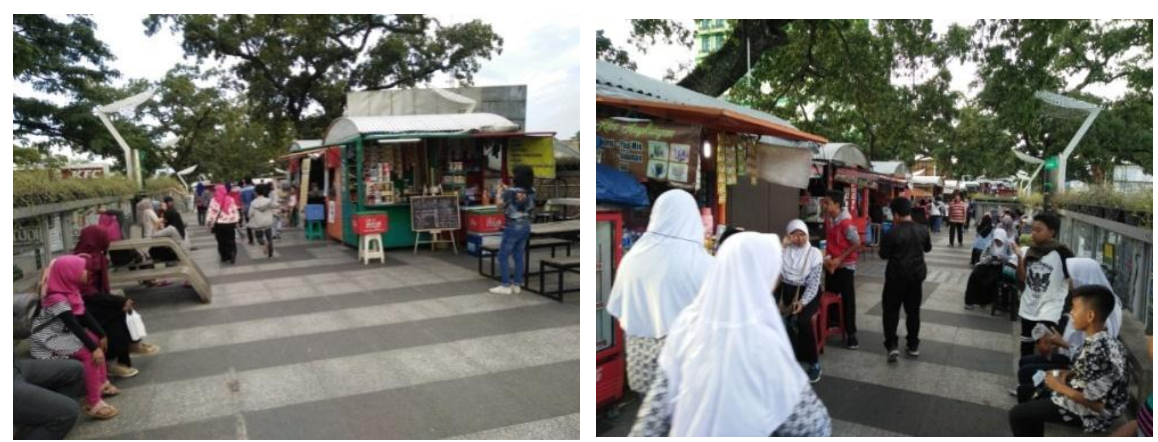

Fig 2:-The culinary selling area is equipped with seating to rest and enjoy the surrounding atmosphere 

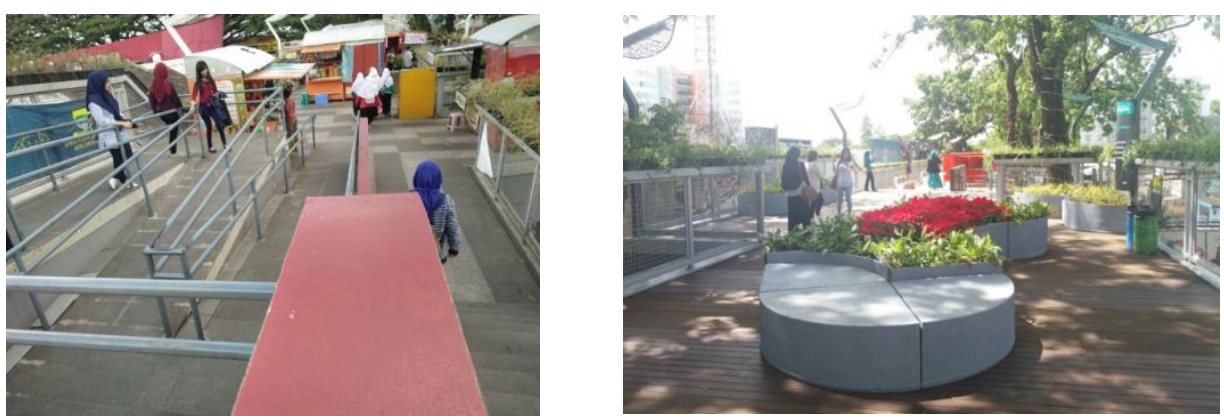

Fig 3:-Supporting elements in the form of parks, photobooths and other landscape elements add value added This area is not just an area for PKL relocation and is still visited and preferred by visitors

This arrangement is quite successful, so that development will be made by making the Cihampelas bridge become longer.

\section{Case Study of Street Vendor Arrangement in Solo City, Indonesia:-}

the implementation of Street Vendor regulation, the Solo Government carried out approaches, providing facilities and infrastructure, as well as the City Government's guarantee of the survival of the PKL's fate. There are three (3) types of approaches namely the Socio-Cultural Approach, the Economic Approach, and the Normative Approach. In addition, support from the Surakarta society also contributed to the successful of this program.

Galabo is a culinary center that only opens at night. Galabo officially occupies a new location in the parking lot of the southeast corner of Vastenburg Fortress. Various specialties culinary of Solo City can be enjoyed here like Rawon, Tengkleng Bu Edi Pasar Klewer, to Sate Kere Yu Rebi and many more.

The concept of this culinary center is to attract tourists from the Solo Culinary aspect. As is well known, Solo Culinary is actually quite diverse and quite attractive to many tourists to come to Solo. The problem is the culinary is quite tasty and famous where it is spread and difficult for tourists to reach all the culinary locations. The central concept of Galabo culinary is to place a well-known street vendor who has famous culinary in Solo in this area. Each culinary entrepreneur here still has a business in his old place, here they are given each small kiosk with the aim of introducing Solo cuisine to the public, especially tourists.

Since the opening of Galabo, visitors are very much, there are live entertainment of keroncong music. it is hoped that in the future Galabo will become one of the tourist destinations that attract tourists in the city of Solo.

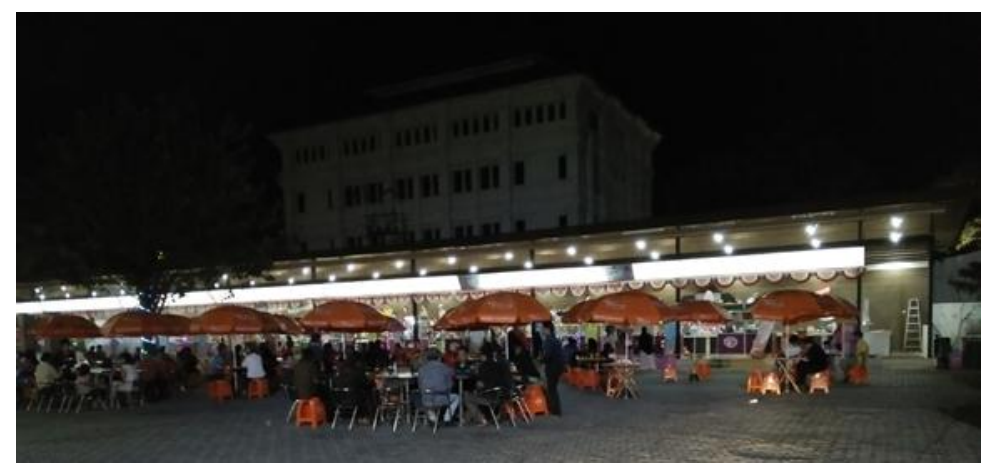

Fig 4:-The atmosphere of the Galabo street vendors area which is now one of the interesting tourist destinations 


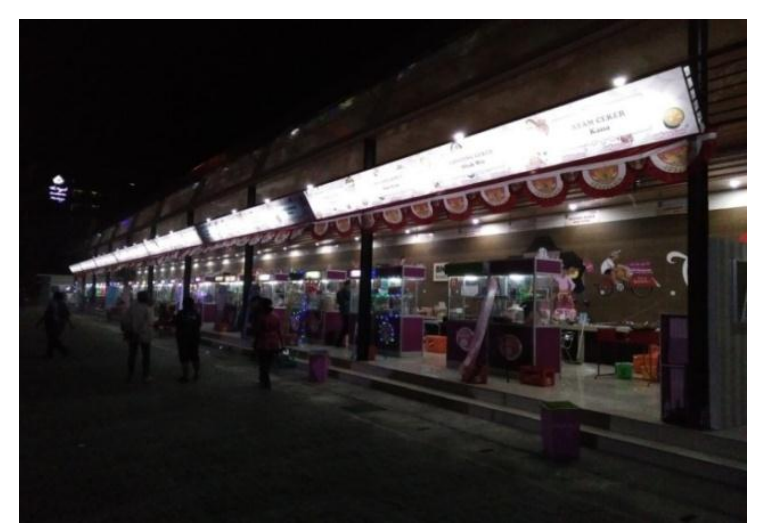

Fig 5:-Rows of neat and attractive kiosks, selling a variety of typical Solo cuisine.

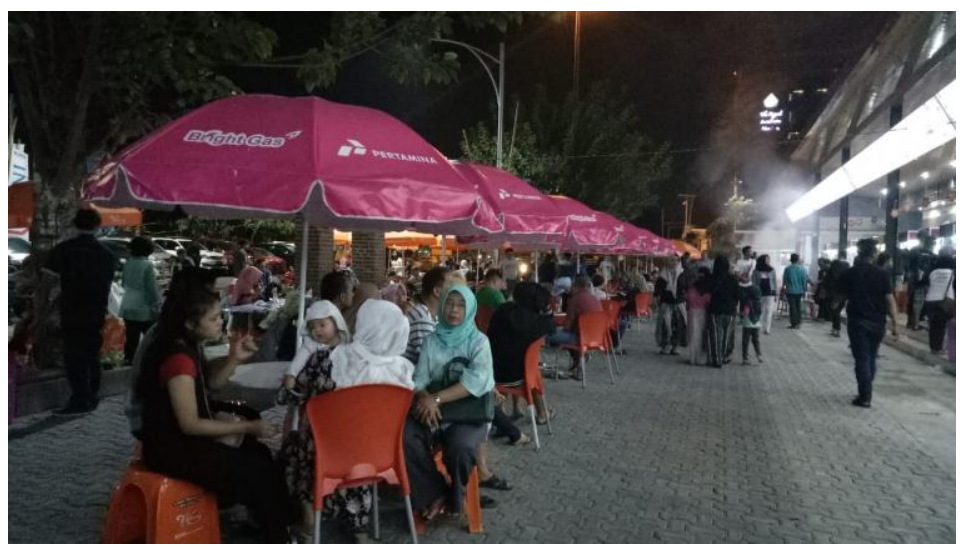

Fig 6:-The open dining area forms is comfortable and relaxed.

\section{Conclusion:-}

1. The local government's policy on street vendor arrangement in the cities of Bandung and Solo has been able to change the impression of less attractive street vendors being one of the city's tourist destinations.

2. This is a good solution for street vendors because they will feel safe and they will not be relocated again.

3. Types of merchandisers must be potential merchants to attract tourists. In the city of Bandung, fashion products are local potential. while in Solo the potential products are cuisine.

4. The location must be strategic and easily accessible for tourists

5. The design of the street vendors should be quite attractive and comfortable seating to enjoy the atmosphere

6. Has supporting facilities like a comfortable pedestrian road, photospot, parks, playground, entertainment stage, etc. 


\section{References:-}

1. Andri Y, Yandi (2008), Journal of Urban Design, Street Vendors as "out of Place" Urban Elements, 13(3), pp 387-402

2. Ala'Eddin, M. K. A. (2012), International Journal of Business Administration, Attractiveness Factors Influencing Shoppers' Satisfaction, Loyalty, and Word of Mouth: An Empirical Investigation of Saudi Arabia Shopping Malls, 3(6), pp101-112.

3. Azizah, Siti, (2017), International Journal of Advanced Research, Location and Design Aspect in Culinary Center Building Design Development For Business Sustainability of Street Vendors in Surabaya, Indonesia , 5 (10). pp 1326-1331

4. Azizah, Siti (2007) Journal of Architecture \& Environment, Street Vendors Arrangement Model Downtown, 6(2),pp 105-113

5. Bromley, R. (2000), International Journal of Sociology and Social Policy,Street vending and public policy: a global review, 20(1/2), pp. 1-29.

6. Bandung City Regional Regulation Number 4 of 2011 concerning the Arrangement and Guidance of Street Vendors

7. Ramadhan, Adam,(2015), Pandecta Journal, Vol 10, no. 1, June 2015, Implementation of Zoning Model for Street Vendor Management in Bandung City, Faculty of Law, Semarang State University, Indonesia

8. Sharma, P. and Dhanwantri, K. (2017), International Applied Scientific Education Research Journal, Application of Materials in Interior Design, 2 (7), pp 3-4.

9. Sitanaya, Octofiany and Handinoto, (2012), Journal of eDimension Architecture, Culinary Tourism Facilities in Surabaya, 1 (1), pp 1-6

10. Madanipour, A. (2004), Journal of Urban Design, Marginal public spaces in European cities, 9 (3), pp. 267-286. 